\title{
Gastric Antral Vascular Ectasia: An Uncommon Cause of Anemia in the Elderly
}

\author{
Rahul Unnikrishnan ${ }^{a}$ Priya Vijayakumar ${ }^{b}$ Sunil Senan ${ }^{b}$ George Paul ${ }^{b}$ \\ ${ }^{a}$ Department of Geriatrics, Rashid Hospital, Dubai, UAE; ${ }^{\text {b }}$ Department of Geriatrics, Amrita Institute of \\ Medical Sciences, Kochi, India
}

\section{Keywords}

Anemia in the elderly - Gastric antral vascular ectasia . Watermelon stomach

\footnotetext{
Abstract

Gastric antral vascular ectasia (GAVE), also referred to as "watermelon stomach," is an uncommon, under-reported, yet significant cause of acute or chronic gastrointestinal blood loss in the elderly. It accounts for about $4 \%$ of the nonvariceal upper GI bleeds, and diagnosis is established by the demonstration of characteristic watermelon stripes on upper Gl endoscopy. The exact cause is unknown but is often associated with many systemic conditions and characterized by chronic anemia. With this case, we wish to emphasize the need to do upper Gl endoscopy in all elderly patients undergoing anemia evaluation and to consider this possibility even in the very elderly individuals.

(C) 2019 The Author(s)

Published by S. Karger AG, Basel
}

\section{Introduction}

Gastric antral vascular ectasia (GAVE), also referred to as "watermelon stomach," is an uncommon, underreported, yet significant cause of acute or chronic gastrointestinal blood loss in the elderly. It accounts for about $4 \%$ of the nonvariceal upper GI bleeds, and diagnosis is established by the demonstration of characteristic watermelon stripes on upper GI endoscopy.

\section{Case Report and Case Presentation}

A 65-year-old female with no known comorbid illnesses presented with complaints of generalized fatigue, loss of appetite, and unquantified loss of weight for the last 4 months. She was evaluated locally 2 months ago and was found to be anemic with a hemoglobin of $10 \mathrm{~g} \%$. She was started on oral iron supplementation, as her iron stores were found to be low, with no significant symptomatic improvement since then. Over the next 2 months, she had

\begin{tabular}{ll}
\hline KARGER & $\begin{array}{l}\text { ๑ } 2019 \text { The Author(s) } \\
\text { Published by S. Karger AG, Basel }\end{array}$ \\
$\begin{array}{ll}\text { Open access } \\
\text { E-Mail karger@karger.com }\end{array}$ & $\begin{array}{l}\text { This article is licensed under the Creative Commons Attribution- } \\
\text { www.karger.com/dmj }\end{array}$ \\
$\begin{array}{l}\text { NonCommercial-NoDerivatives 4.0 International License (CC BY- } \\
\text { NC-ND) (http://www.karger.com/Services/OpenAccessLicense). } \\
\text { Usage and distribution for commercial purposes as well as any dis- } \\
\text { tribution of modified material requires written permission. }\end{array}$
\end{tabular}

Dr. Rahul Unnikrishnan

Department of Geriatrics, Rashid Hospital Dubai Health Authority

Dubai, PO Box 4545 (UAE)

E-Mail dr.rahulunnikrishnan@gmail.com 


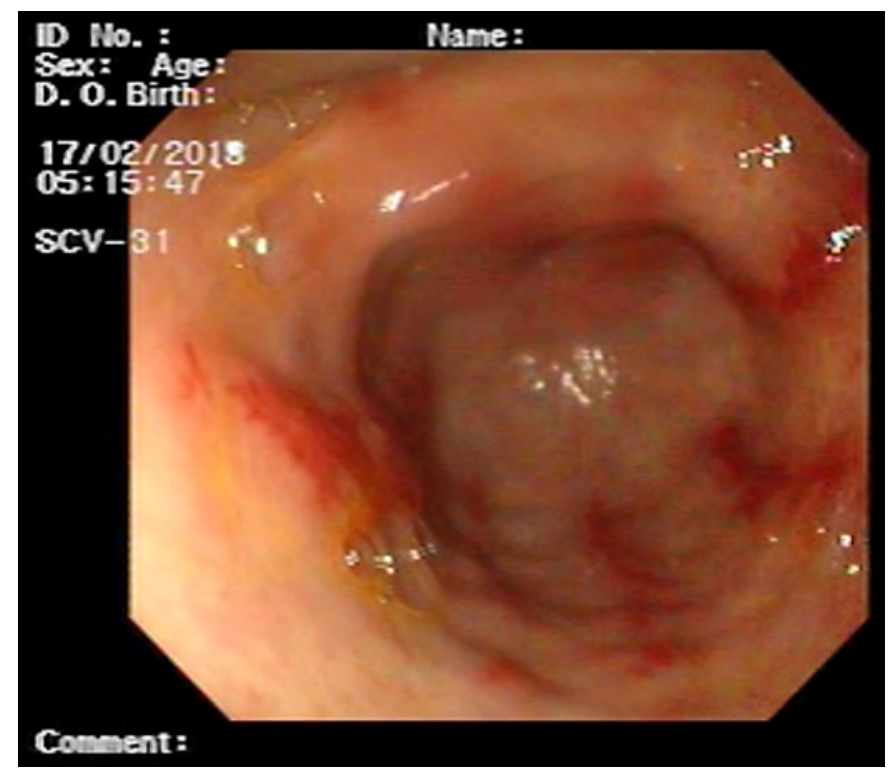

Fig. 1. Watermelon stomach.

persistent complaints of generalized edema and occasional bouts of diarrhea. She did not have any associated overt bleeding manifestations. Routine evaluation revealed iron deficiency anemia, and stool occult blood was positive. This warranted the second line of anemia evaluation. Upper GI endoscopy revealed GAVE (Fig. 1, 2 ). Argon plasma coagulation was done, and her occult blood loss ceased. On follow-up, her hemoglobin levels gradually improved, and she continued to be asymptomatic, as her earlier symptoms had largely resolved.

\section{Discussion and Conclusion}

GAVE is an uncommon but significant cause of acute or chronic GI blood loss in the elderly. It was first described by Rider as "fiery red changes with marked hypertrophic mucosal changes, and scattered profuse bleeding" in 1954.

Seen more commonly in females $(5: 1)$, patients may initially present with features suggestive of transfusiondependent chronic iron deficiency anemia, severe upper GI bleeding, or even gastric outlet obstruction. The condition is often associated with hypertension, diabetes, renal failure, gastric carcinoma, aortic stenosis, and with autoimmune diseases such as Sjogren's syndrome, systemic lupus erythematosus, primary biliary cirrhosis, and systemic sclerosis. GAVE is characterized by a pathognomonic endoscopic finding of red spots in a stripe pattern extending radially from the pylorus (watermelon stomach), or presents as a diffuse pattern (honeycomb stom-

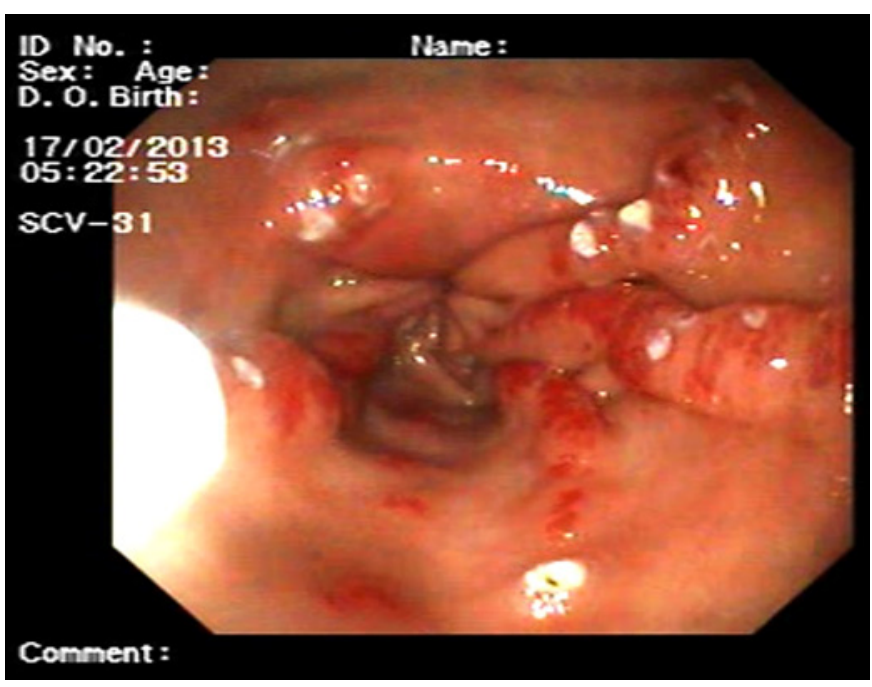

Fig. 2. Radial extension of red stripes from the pylorus of the stomach.

ach) [1]. Histology, though, is not pathognomonic, and four patterns have been largely described: vascular ectasia of mucosal capillaries, spindle-cell proliferation, focal thrombosis, and fibrohyalinosis.

The main differential diagnosis is portal hypertensive gastropathy and may even be co-existent. Portal hypertensive gastropathy primarily involves the fundus and corpus of the stomach though, and the histological pattern is different. It is important to differentiate between the two because of the diametrically opposite therapeutic approach to either of them. Endoscopically, PHG shows a combination of mosaic-like pattern, red point lesions, cherry-red spots and black-brown spots, and often responds to beta blockers, transjugular intrahepatic portosystemic shunt, and portocaval shunts. This response is characteristically absent with GAVE.

Pathogenesis is largely nondescriptive, and various hypotheses have been put forward. Mechanical stress due to strong gastric peristalsis induces prolapse and trauma of the antral mucosa and intermittent obstruction of blood vessels, which leads to fibromuscular hyperplasia and vascular ectasia. Certain authors attribute this to spindle cell proliferation due to humoral factors such as gastrin, vasoactive peptide, 5-HT, glucagon, catecholamines, prostanoid, and other undefined vasoactive substances resulting in increased venous hydrostatic pressure or due to vasodilation secondary to high levels of such vasoactive substances due to local proliferation of neuroendocrine cells [3]. 
Two main forms have been described in the literature:

(a) Classic form: prominent erythematous streaks traversing the antrum and converging on pylorus; idiopathic onset and is usually associated with systemic sclerosis and pernicious anemia.

(b) Diffuse variety: discrete angioma extends proximal to the antrum and is found associated with cirrhosis and portal hypertension [4].

Treatment for GAVE is basically divided into three broad categories - pharmacologic, endoluminal, and surgical. Though avoidance of agents that cause mucosal bleeding and irritation such as NSAIDs, aspirin, and clopidogrel are important, options such as corticosteroids, estrogen-progesterone combinations, tranexamic acid, thalidomide, alpha-interferon, calcitonin, and cyproheptadine have been explored, but with limited efficacy $[5,6]$.

Endoluminal therapies are the mainstay of conservative treatment and include options such as endoscopic band ligation, sclerotherapy, heater probe, and argon plasma coagulation, which is the preferred endoscopic treatment and is reported as safe. Neodymium-yttriumaluminium garnet (Nd: YAG) laser coagulation has been successful to control GAVE-related bleeding.

The most serious complication following laser therapy is gastric perforation. Another observed complication is pyloric stenosis that can induce either delayed gastric emptying or true obstruction [7, 8]. A major disadvantage of laser endoscopic therapy is its high cost, and the risk of complication dependent on the endoscopist's skills. Ar- gon plasma coagulation (APC) is a non-contact technique with a controllable depth of coagulation. In comparison to Nd: YAG laser therapy, APC is easier to use, manageable, cheaper and, most importantly, safe [1]. Primary surgical treatment is not advocated because of the reported high morbidity and mortality of patients with GAVE syndrome undergoing surgery who often have multiple other medical comorbidities.

\section{Statement of Ethics}

General consent was obtained from the patient.

\section{Disclosure Statement}

The authors have no conflicts of interest to declare.

\section{Funding Sources}

The authors did not receive any funding.

\section{Author Contributions}

R.U. author: conception of the case report and data collection. S.S. co-author: critical review of the article and data analysis. P.V. co-author: critical review of the article.

G.P. co-author: critical review and final approval.

\section{References}

1 FuccioL, Mussetto A, Laterza L, Eusebi LH, Bazzoli F. Diagnosis and Management of Gastric Antral Vascular Ectasia. World Gastroint Endosc. 2013 Jan;5(1):6-13.

2 Nguyen $H$, Le C, Nguyen H. Gastric antral vascular ectasia (watermelon stomach)-an enigmatic and often-overlooked cause of gastrointestinal bleeding in the elderly. Perm J. 2009;13(4):46-9.

3 Quintero E, Pique JM, Bombi JA, Bordas JM, Sentis J, Elena M, et al. Gastric mucosal vascular ectasias causing bleeding in cirrhosis. A distinct entity associated with hypergastrinemia and low serum levels of pepsinogen I. Gastroenterology. 1987 Nov;93(5):1054-61.

4 Pasumarthy L, Srour J. Gastric antral vascular ectasia: an uncommon cause of GI bleeding. Pract Gastroenterol. 2009 Feb:34-6.

5 Rider JA, Klotz AP, Kirsner JB. Gastritis with veno-capillary ectasia as a source of massive gastric hemorrhage. Gastroenterology. 1953 May;24(1):118-23.

6 Selinger CP, Ang YS. Gastric antral vascular ectasia (GAVE): an update on clinical presen- tation, pathophysiology and treatment. Digestion. 2008;77(2):131-7.

7 Mathou NG, Lovat LB, Thorpe SM, Bown SG. Nd:YAG laser induces long-term remission in transfusion-dependent patients with watermelon stomach. Lasers Med Sci. 2004;18(4): 213-8.

8 Liberski SM, McGarrity TJ, Hartle RJ, Varano $\mathrm{V}$, Reynolds D. The watermelon stomach: long-term outcome in patients treated with Nd:YAG laser therapy. Gastrointest Endosc. 1994 Sep-Oct;40(5):584-7. 